\title{
Factors related to the term "Halal" affecting the Purchase Intention of Non-Muslim Consumers in Bangladesh
}

\author{
Abul Khair Jyote, Independent University, Bangladesh, akj.iub@iub.edu.bd \\ Dhritiparna Kundu, Independent University, Bangladesh, dhritiparnakundu@gmail.com
}

\begin{abstract}
The Halal concept commonly concerns Muslim consumers. But nowadays, it is also being attractive for non-Muslim customers. The rising anxiety on health, a halal diet business strategy nowadays has huge budding in taking non-Muslim as a target audience as well. General consumers are not only adopting this concept for the religious value; but also, they prefer it for its hygiene, cleanliness and the quality of food. For that reason, this product concept is creating hyped in Bangladesh. At this moment general consumers are aware of environmental pollution, adulterated food products, animal welfare. Hence, they like to prefer trustworthy sources for product consumption which will help them to care about society. As a result, Local companies are taking this advantage and creating hype by offering Halal items. Mostly every religion's people like to buy halal items for adopting the safe side. Because they believe that for the religious promise companies will maintain the product quality which will safe to consume. Now, many renowned brands that are offering Halal product lines to attract customers in Bangladesh. As Bangladesh is a Muslim country, easily this concept is being appreciable to everyone. Moreover, after considering the rising demand for Halal products Bangladesh government has currently providing certification for Halal food manufacturing and food outlets facilities inside the country (Nisha and Iqbal, 2017).
\end{abstract}

However, the data has been collected through the structured close-ended questionnaire survey consisting of 121 non-Muslim communities in Bangladesh. The analysis supported Halal awareness, Halal certification; marketing promotion and Brand were constructively correlated with the purchase intention. The time duration of the data collection was more than two weeks. Basically, the aim of this study is to identify the factors which affect the purchase intention of non-Muslim consumers to buy Halal items in Bangladesh.

Keywords: Halal awareness, Halal certification, quality product, purchase intention, Bangladesh.

\section{Introduction}

Halal, which signifies "admissible" or "permitted" in Arabic, is basically a lifestyle and isn't exclusively restricted to the kinds of food that a Muslim is permitted to devour. However, nourishment is a fundamental part of the sustenance expected to have a significant existence. In Islam Halal is not just a concept or ritual, it's like how can people prepare the food by maintaining safety, hygiene, and healthiness (Golnaz, Zainalabidin, Mad Nasir \& Eddie Chiew, 2010). Besides, Halal food represents healthy eating. And people can able to live a healthy life, who usually 
follow this idea. Nowadays, people become more conscious of their daily life. Today, Halal is no longer an insignificant strict commitment or recognition yet is considered as the standard of decision for Muslims just as non-Muslims around the world (Golnaz et al., 2010). Not only the Muslim but also non-Muslim people all over the world have knowledge about the Halal concept. And they also get an idea about the good side of it. As per Canadian Agri-Food Trade Service Report (2008), there is a huge demand for Halal goods in a number of non-Muslim states forever group of customers. Halal items are also being very popular in Bangladesh because of the trustworthiness of religious issues.

\section{Literature Review}

The halal market is assessed to be worth US\$580 billion every year internationally and the halal nourishment ventures evaluated development rate is 7\%annually (Aziz and Chok, 2013). Basically, the halal growth status can be connected to religious rituals and beliefs that it is disinfectant, healthier, and delicious (Burgmann, 2007). Now, people consider the halal logo as the symbol of quality items with religious fulfillment (Burgmann, 2007; Aziz and Chok, 2013). Today, non-Muslim consumers are also adopting halal products, because they believe that by this concept people being humanitarian to animal treatment. Because of religious belief, general people trust that halal products are more hygienic and safer to consume (Golnaz et al., 2010).

This article develops a conceptual framework, which represents the correlation between the halal awareness, halal certification, food product quality, marketing promotion, and brand with purchase intention of halal products in Bangladesh. Each variable has been selected by the analysis of previous studies.

\section{Halal Awareness}

Nowadays, Bangladesh has seen a rising interest for Halal items and administrations as its Muslim population has gotten progressively mindful of their strict command and that's just the beginning touchy to non-Halal items and administrations (Rahman et al., 2014; Nisha and Iqbal, 2017). As a result, halal items are increasing day by day in the Bangladeshi market. According to the previous study, just halal labeling of the halal product is may not refer to Halalization. The flavor, color, and ingredients selection are also should be included in this process to make it more authentic (Ismail and Ehsan, 2008). As non-Muslim people have limited knowledge about halal food, they just consider the label and logo too by any halal items. Because, they think that halal food is more hygienic, wholesome and taster because of its quality maintaining process (Aziz and Chok, 2013). According to previous studies, for the awareness about quality foods, non-Muslim people are being motivated to purchase halal items. So, it can be said that people's purchase intention of halal items depends on the awareness about quality food (Aziz and Chok, 2013).

\section{Halal Certification}

According to a previous study Islamic finance is creating at a noteworthy pace and the utilization of Halal-certified items and administrations has gotten an incredible showing power all over the world (Nisha and Iqbal, 2017). Furthermore, Halal documentation refers to the authorized recognition of the arranged process of research, slaughtering, cleaning, management and other related supervision practices by the conventional body (Aziz and Chok, 2013). In South Asia, Muslim countries are growing rapidly and most of the country is following the halal business concept (Nisha and Iqbal, 2017). By representing the hygienic and wholesomeness this concept being popular day by day. For that reason, different brands are using the halal symbol on their product's packaging to make it trustworthy to the customers. At this moment, ensuring the utilization of Halal items and services is a focal part of the social personality of Southeast Asian Muslims (Iqbal and Nisha, 2016). As being a Muslim state Bangladeshi business industry is also 
following the Halal concept. Bangladeshi consumers have a strong awareness of halal items (Nisha and Iqbal, 2017). Basically, qualified halal items are an obligation for the Muslim as part of religious requirements. But interestingly, Muslim and non-Muslim people both are preferring halal items for their daily consumption purpose (Aziz and Chok, 2013). Because, they consider halal food more nutritious, healthy, clean and well prepare. With the help of social media and traditional books, people are getting an idea about the halal concept, that is why non-Muslim people are also being interested in it. For that reason, halal certification is necessary. But Muslims in Bangladesh think that only advertisement and promotional campaign is not enough to make the people aware of halal items. Now, Bangladesh is taking various steps to make the concept authorized (Islam and Chowdhury, 2018). There is observational proof to help the reason that non-Muslims are worried about food hygiene, which positively impacts the possibility of their attitude on the halal product (Golnaz et al., 2010; Aziz and Chok, 2013). The previous study shows that the certification of halal food is being trustworthy to non-Muslim customers and they feel positive to buy those items which are authorized by Government. So, it is proven that authorized halal products are influencing non- Muslim consumer's buying perception (Golnaz et al., 2010; Aziz and Chok, 2013).

\section{Product quality}

For a consumer quality product is the main concern before purchase. Product quality or food quality refers to physical creation aspects such as taste, appearance, and other qualities (Aziz and Chok, 2013). Moreover, Quality is an attractive trait of an item or service that is required by the consumers (Canavari, Castellini \& Spadoni, 2010). Additionally, purchaser acknowledgment is regularly the way to progress the extent that the food maintenance strategy is concerned. The general rules in Islam express the particular thought processes behind the halal idea (Lampila and Lähteenmäki, 2007). Not only for religious value, but also the purposes also include preserving life, to safeguard upcoming generations, and to maintain self-esteem and truthfulness (Muhammad, Norhaziah, Nuradli and Hartini, 2007). With the help of a halal concept, the producer can ensure quality products. And for that reason, general people nowadays are relying on halal food. As a result, the Halal concept being acceptable and trustworthy for non-Muslims; because it representing the quality product in front of everyone. As indicated by Newberry, Klemz, and Boshoff (2003), product quality is viewed as one parameter in foreseeing purchase intention. So it can say that product quality has a positive correlation with consumer's purchase intention. Because only this factor can able to change the whole purchasing scenario.

\section{Marketing promotion}

To communicate with consumer promotion is the best way which can help to achieve the goal (Aziz and Chok, 2013). Nowadays, with the help of social media people have an idea about many products and services. With the help of media activation now non-Muslims also have an idea about the halal concept. As per Christian (1994), the marketing mix can impact a firm's focused position. Advancement is a helpful promoting apparatus (Kotler and Armstrong, 2006), which may impact buy among customers. With the end goal of the present investigation, food product promotion is characterized as the showcasing and deals advancements utilized on the halal food logo or as halal food bundling intended to lure purchasers to buy an item at the purpose of-offer (Hawkes, 2004). Advancements may comprise premium offers, for example, giveaways and rivalries; premium supports; what's more, animation and celebrity advancements (Hawkes, 2004; Aziz, and Chok, 2013). Basically, advertising promotion has a particular job in making brand awareness, create favorable brand frames of mind and invigorate purchasing goals (Belch and Belch, 1998; Rossiter and Percy, 1997; Aziz, and Chok, 2013). After analysis of the previous studies, it can be said that marketing promotion helps the consumer to make a better decision about the purchase. 


\section{Brand:}

To buy a product and service brand name creates a trustworthy and faithful situation. Before buy products or service customers think about it because a particular amount they have to pay for that product. As indicated by Dodds and Monroe (1985), the brand name has outward quality cues. Brand names as a rundown develop for quality since it has to surmise quality dependent on brand name (Han, 1989; Aziz, and Chok, 2013). A specific brand may not exclusively be spoken to by a name or images. It speaks to customers' discernment and notion toward the item and service, which intends to the buyers' point of view. (Kotler and Amstrong, 2006; Aziz, and Chok, 2013). According to previous studies, the brand name has a strong motivation power which can influence customer's buying attitude (Alreck \& Settle, 1999; Ataman \& Ulengin, 2003; Aziz, and Chok, 2013). Customers' expectation to buy an item or service can be impacted by an uplifting frame of mind toward the brand itself (Laroche \& Brisoux, 1989; Aziz, and Chok, 2013). According to Theory plan behavior, consumers would choose a brand that is similar to its characteristics. For example, if any renowned brand promoted that they are adopting the halal concepts in their product, then they can successfully able to influence the customer to buy their products frequently (Aziz, and Chok, 2013).

\section{Intention to purchase}

Customer purchase intention depends on consumer attitude. The previous study suggested that purchase intention is known as a sentiment of client that was persuaded to buy item or service which make the client fulfilled or see the distinction of item from others (HSU and NGAMNATE, 2018, citing Keller, 2001). In the context of this study, it is anticipated that people carry on as indicated by an anticipated system as recommended by Ajzen (1989) in buying halal food. Thusly, attitude toward behavior, which started from an aggregate conduct conviction, for example, the conviction that the item is halal, may prompt great dispositions, for example, having the expectation to buy. The subjective norm is another capacity of conviction, which is seen as a social strain to draw in or not to participate in that specific conduct (Aziz \& Chok, 2013). A previous study shows that non-Muslim customer's attitude towards halal food and items varies from time to time. But for brand awareness and marketing promotions are growing rapidly. So, halal segmentation and non-Muslims people's usage of halal items are also increasing rapidly (Golnaz et al., 2010). So, it can be said that non-Muslim people's purchase intentions positively influenced by the brand, marketing promotion, halal awareness, and halal certification.

\section{Conceptual Framework:}

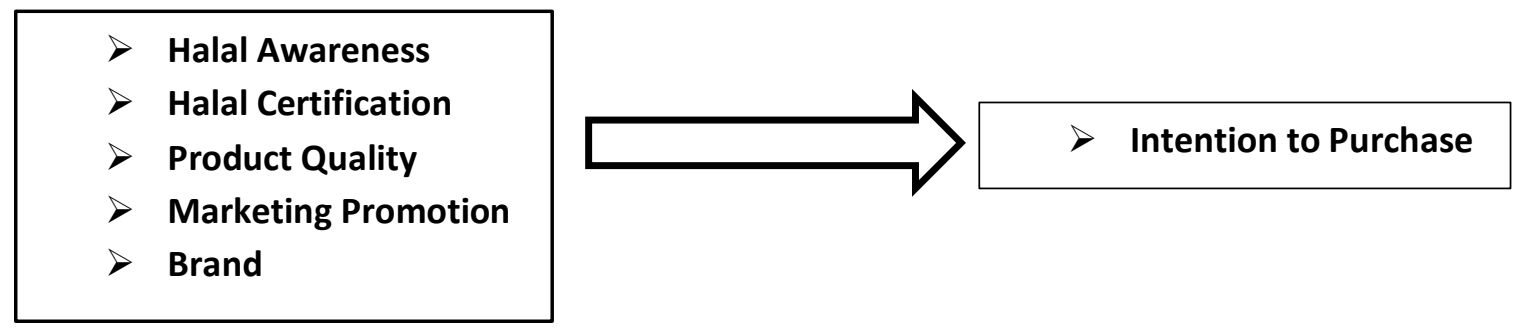

\section{Methodology}

The purpose of the study is to identify the elements that influencing purchase intention about halal products. To achieve this reason, we tried an examination demonstrate by making a questionnaire survey to gather information. We prepared a questionnaire with the help of Google Doc. After preparing it we shared the questionnaire link to our personal social media account. And we have also requested some admin who has their own social media pages. Our target audience is mostly non-Muslims people in Bangladesh who are regularly connected with social 
networking sites and following and watching different brand promotional activities on a regular basis.

The five-point Likert scale was selected for data measurement purposes. The questions are ranging from "Strongly Disagree" =1, "Disagree" =2, "Neutral" =3, "Agree" =4 and "Strongly Agree" $=5$. The research questions cover two parts. There are five demographic questions, where we have asked participants' gender, age, religion, profession, income, the education-related question to gather basic information about participants. Then we have asked the variable related questions. Like- Halal Awareness, Halal certification, Product quality, Marketing promotion, Brand, etc. which consider independent variables. And we have included thirteen questions in the questionnaire which we have adopted (Shaari and Arifin, 2009). Additionally, Consumer purchase intention in considers as a dependent variable in this study. And we have selected six questions for the questionnaire arrangement purpose, which we have adopted from (Lada, Tanakinjal, and Amin, 2009). We have assured the participants that we will keep their personal information confidential. And it was mention that this data will only use for academic research purposes. The quantitative data collection method was selected because of the short time period. We have collected data from 121 participants which took one week to gather information. Our sample was Bangladeshi non-Muslim people who have an idea about the halal concept and using these kinds of products and services on a regular basis. The sample size was not so large because of the sort time period. Moreover, for the data analysis purpose, descriptive analysis, reliability test, Pearson, superman, and regression analysis has been used to identify the correlation; strengths and weakness between variables.

\section{Data analysis and result}

\section{Descriptive analysis}

In this study, the sample size was 121 who are non-Muslim. In the sample there were $108 \mathrm{Hindu}$, 7 were Christian and 6 people follow Atheism and Buddhism. Here, 54 were female study and 67 who have an idea about Halal products and regularly using it. Mostly, $77.7 \%$ of people are belonging to 18-25 years old. Moreover, 91 respondents were students from the total respondents, and $51.2 \%$ of participants have no regular income source. And $91.1 \%$ of participants were unmarried. After analysis, the whole scenario it can be said that not only the mature and well income people; but also the young generation have the awareness about fresh food and they like to buy Halal items to consider in fresh and wholesome. Additionally, they have a limited income that is why they do not want to take any risk to experience bad services. For that reason, they like to go for Halal zone to think about health benefits.

\section{Reliability Analysis}

The Reliability test is directed to gauge inner consistency. The unwavering reliability coefficient of 0.7 is satisfactory, more than 0.8 is great and more than 0.9 is viewed as Excellent (George and Mallery, n.d.; quoted in Namdeo and Rout, 2017). Here, in the reliability test, Cronbach's alpha value is showing the inner consistency of dependent and independent variables. The analysis shows Product quality, marketing promotion, and Brand value is more than 0.8 which expresses good consistency. On the other hand, Halal awareness, Halal certification, and Intention to purchase Cronbach's alpha value are more than 0.9 which shows excellent internal consistency.

\section{Pearson analysis}

Pearson analysis identifies the positive and negative relationships between variables. Here, Halal certification .571, Halal awareness .659, Marketing promotion .581, Product quality .433 and Brand value is .366 which represents the positive relationship between variables. On the other hand, the p-esteem is 0.000 , which is under 0.01 . Along these lines, the null hypothesis in this 
exploration can be rejected and it tends to be presumed that there is a positive connection between the independent variables and the dependent variable. Spearman analysis:

This analysis usually helps to reveal the correlation strength between variables. Here, Brand and product quality's values are .322 and.308, which represents a week correlation with the intention to purchase. On the other hand, marketing promotion represents a moderate relationship. And Halal certification, Halal awareness value is .652 which reveals a strong correlation with the dependent variable. So, it can be said that non-Muslim people in Bangladesh do not feel any quality difference between Halal and non-Halal items. Moreover, here the Brands are also inactive to provide Halal items to their customers.

\section{Regression Analysis}

Regression investigation gives the thought regarding connections among factors and it additionally demonstrates how much they impact one another. In this study, the $\mathrm{R}^{2}$ value is .446 and the adjusted $R^{2}$ value is .432 which shows how much the dependent variable is clarified by all the independent variables together. Spearman's relationship coefficient can run in an incentive from -1 to +1 . The bigger the supreme estimation of the coefficient, the more grounded the connection between the factors. Positive esteem shows a positive connection, while negative esteem demonstrates a negative connection among variables. Here, the P-value of items quality $=.158$, Brand $=.388$ and Marketing promotion $=.468$ which represents the moderate relationship between variables. On the other hand, Halal awareness and Halal certification's value is .000 which reveals a significant correlation with the intention to purchase. So, it is proven again that non-Muslim people in Bangladesh cannot find the difference in Halal product's quality. Moreover, the brands are not aware of Halal food's marketing promotion.

\section{Findings, limitations, and recommendation for further research}

The data analysis shows the positive relationship between independent and supporting variables. If we consider descriptive analysis; then we can see that, $51.2 \%$ which is half of the participants who have no regular income and other $48.8 \%$ who have a stable income source. So, it can be said that both employed and unemployed people have a general idea about halal food. And they are using those products and services on a daily basis. On the other hand, $90 \%$ of participants were unmarried. So it is also safe to say that, not only married family-oriented people but also young unmarried citizens in Bangladesh are using Halal items for leading a healthy life.

On the other side, if we consider the reliability and regression analysis then it's showing that Brand and Food quality has a week relationship with intention to purchase. So it can say that non-Muslim people in Bangladesh cannot feel any difference between Halal and non-Halal items. So it can be assumed that most brands are unaware of the halal food process. And most employees are not well trained here to process halal items. For that reason, people cannot find any difference in food processing. As a result, the quality assurance level is zero here. On the other side, the analysis part shows that Brand and marketing promotion has also a moderate relationship with purchase intention. So it can assume that renowned brands in Bangladesh are not introducing and promoting halal items and services. For that reason, people in Bangladesh have a limited idea of halal items. As a Muslim country, Bangladeshi brands need to increase awareness about halal items and services by promoting this concept. Also, the Government should encourage different brands in Bangladesh to introduce and promote the halal concepts to leading a healthy life. Also, Companies should arrange talk shows, seminars, and campaigns for teaching the benefits of halal consumption. Oppositely, governments and organizations should offer different training, so that employees become skilled in food processing by following the halal concept. 
There were some limitations to this study. We believe that, as we have used a qualitative data collection method which is not enough for this study. For the in-depth analysis, we need to collect qualitative data as well. Because, if we can make some people's face to face interviews who are non-Muslim and consume halal items on a daily basis. Moreover, the time duration for this study was two months, which is considered a cross-sectional study. If we get more time than the result could be different and more positive.

Alternatively, our sample size was 121 which is not enough to get a proper result. On the other side, as Bangladesh is a Muslim state that is why it was very difficult to get non-Muslim participants who have a complete idea about the halal concept. Even some participants had no idea about the halal concept. For that reason, it was difficult to gather appropriate data. Moreover, People do not have an idea about any significant brands or companies who are offering halal items on a regularity basis. They just buy a product after see the halal logo or stamp. So that reason, they have no faith in the companies that are selling halal items in Bangladesh. So, a recommendation it can be said that the Government should take necessary steps to maintain the food quality through the halal process. And every company should introduce halal food and service sections with proper information chart. So that, not only Muslims but also non-Muslim customers can feel the interest to buy this kind of product for their better health purpose. In this way, people in Bangladesh can maintain the quality of products to obey religious factors. On the other side, non-Muslim people will also get the benefit to consume quality products through the halal concept.

\section{Conclusion}

Respondents who participated in this study have shown a positive attitude about halal food. And it is also proven that non-Muslim people in Bangladesh cannot feel any difference between halal and non-halal items. So, it can be said that the food processing system needs to be monitored. Besides, there is a scarcity of skilled labor in Bangladesh. So it can be assumed that for that reason people cannot feel any difference between halal and non-halal items. Moreover, according to the analysis part, brand and product quality has a week relationship with consumers' purchase intention. So, it can be assumed that in Bangladesh there have not any significant brands that are seriously promoting halal goods. For that reason, non-Muslim people in Bangladesh are unaware of the halal brand. Additionally, some brands do not maintain the quality for that reason most people cannot feel any difference. As a result, they buy items that are frequently available. However, our study has given proof of the presence of halal awareness among the non-Muslim people group in Bangladesh. Also, this study highlights the correlation with consumers' purchase intention towards halal foods. And it is proven that non-Muslim people in Bangladesh have a positive assertiveness with halal items and services. So it can be said that, if different companies in Bangladesh offer a halal section with hyped promotional activities then non-Muslim people will also being dependent on halal items. Because in Bangladesh most of the company does not maintain proper hygiene, On top of that harmful chemical, preservative, and colors, etc. is continuously using in the food items to make it long-lasting. For that, reason, if a brand is offering quality food, not only Muslims but also non-Muslim, will be attracted to halal items and services. 


\section{References}

Alreck, P. L., \& Settle, R. B. (1999). Strategies for building consumer brand preference. Journal of product \& brand management, 8(2), 130-144.

Ataman, B., \& Ülengin, B. (2003). A note on the effect of brand image on sales. Journal of Product $\mathcal{E}$ Brand Management, 12(4), 237-250.

Aziz, Y. A., \& Chok, N. V. (2013). The role of Halal awareness, Halal certification, and marketing components in determining Halal purchase intention among non-Muslims in Malaysia: A structural equation modeling approach. Journal of International Food \& Agribusiness Marketing, 25(1), 1-23.

Belch, G. E., \& Belch, M. A. (2003). Advertising and promotion: An integrated marketing communications perspective. The McGraw- Hill.

Burgmann, T. (2007). Growing Muslim population pushing companies to produce products they can eat. The Star.

Canadian Agri-Food Trade Service,Global Halal Food Market Brief. June 2008. http://www.atssea.agr.gc.ca/africa/4491_e.htm

Canavari, M., Castellini, A., \& Spadoni, R. (2010). Challenges in marketing quality food products.

Christian, G. (1994). From Marketing Mix to Relationship Marketing. Towards a Paradigm Shift in Marketing. Management decision, 32(2), 4-20.

Dodds, W. B., \& Monroe, K. B. (1985). The effect of brand and price information on subjective product evaluations. ACR North American Advances.

George, D., \& Mallery, M. (2003). Using SPSS for Windows step by step: a simple guide and reference. $4^{\text {th }}$ ed. London: Pearson Education.

Golnaz, R., Zainalabidin, M., Mad Nasir, S., \& Eddie Chiew, F. C. (2010). Non-Muslims' awareness of Halal principles and related food products in Malaysia. International Food Research Journal, 17(3), 667-674.

Han, C. M. (1989). Country image: halo or summary construct?. Journal of marketing research, 26(2), 222-229.

Hawkes, C., \& World Health Organization. (2004). Marketing food to children: the global regulatory environment.

HSU, Y., \& NGAMNATE, N. (2018). Factors Affecting Electronic Word-of-Mouth (E-WOM) Usage on the Customer Purchase Intention: An Investigation on Beauty Market. International Journal of Business and Social Science, 9(4).

Islam, M. M., \& Chowdhury, M. A. F. (2018). Consumers' buying decision process toward halal product: a study in Bangladesh. International Journal of Business Innovation and Research, 16(3), 285-301.

Ismail, Z., \& Ehsan, A. H. (2008). Halal nutraceutical market: issues and challenges. In Proceedings of the Asian Forum on Business Education 2008 on Contemporary Issues in doing Business in Asia, 3-4 December. University of Malaya.

Kotler, P., \& Armstrong, G. (2006). Principles of marketing 11th ed. 
Lada, S., Harvey Tanakinjal, G., \& Amin, H. (2009). Predicting intention to choose halal products using theory of reasoned action. International Journal of Islamic and Middle Eastern Finance and Management, 2(1), 66-76.

Lampila, P., \& Lähteenmäki, L. (2007). Consumers' attitudes towards high pressure freezing of food. British food journal, 109(10), 838-851.

Lane Keller, K. (2001). Mastering the marketing communications mix: Micro and macro perspectives on integrated marketing communication programs.

Laroche, M., \& Brisoux, J. E. (1989). Incorporating competition into consumer behavior models: the case of the attitude-intention relationship. Journal of economic psychology, 10(3), 343-362.

Muhammad, N., Norhaziah, N., Nuradli, R., \& Hartini, M. (2007). Halal Branding: An Exploratory Research among consumers in Malaysia. Available at nuradli. com.

Newberry, C. R., Klemz, B. R., \& Boshoff, C. (2003). Managerial implications of predicting purchase behavior from purchase intentions: a retail patronage case study. Journal of Services Marketing, 17(6), 609-620.

Nisha, N., \& Iqbal, M. (2017). Halal Ecosystem: Prospect For Growth In Bangladesh. International Journal of Business and Society, 18(S1), 205-222.

Percy, L., \& Rossiter, J. R. (1997). Advertising communications and promotion management. (2nd ed.), New York, NY: McGraw-Hill.

Rahman, M. M., Khatun, M., Rahman, M. H., \& Ansary, N. P. (2014). Food safety issues in Islam. Health, Safety and Environment, 235(1371), 1-14.

Shaari, J. A. N., \& Arifin, N. S. (2009). Dimension of halal purchase intention: A preliminary study.International Review of Business Research Papers, 6(4), 444-456. 